\title{
Response
}

\section{An Alternative Model}

\author{
Brian Chezum
}

St. Lawrence University, 23 Romoda Drive, Canton NY 13617, USA.

Eastern Economic Journal (2016) 42, 488-490. doi:10.1057/eej.2016.12

Professor Colander's essay, "The Economics Major is Not a Pipeline to Finance," highlights a reality confronted by many economics professors at liberal arts schools that do not offer a traditional business major. The economics major is viewed by students as the logical substitute to a business major and as a consequence we are the most popular major on campus. I am sympathetic to the challenge this may create in the classroom, Colander argues that some "30 to 40 percent of our majors are majoring in economics not because they love economics." I would not dispute the greater joy I receive when teaching students possessing a passion for economics, but there are hidden benefits from those studying economics only to pursue a career in business. The best of these students are aware of the news and bring interesting "business" questions to the classroom. These questions provide economics professors the opportunity to highlight the power of the analytical tools we as economists employ.

Before we encourage our students to abandon economics as a major, we should minimally evaluate the evidence. Black et al. [2003] using a sample of 85,000 individuals with a college degree find that "economics majors generally fare well, earning significantly more than graduates with the most popular major, business administration, and more than other social science majors, humanities majors and arts majors. Only engineering majors earn significantly more than economics majors." Results similar in flavor are reported by Altonji et al. [2012]. Why the differential? Black et al. provide three potential explanations. First, economics training may be particularly productive in the market place; second, wages may reflect compensating differentials driven by preferences (musicians may accept lower wages for the love of music); third, selection across majors, higher average ability individuals may be choosing economics as a major because of its relative rigor. In this framework, the economics major provides a valuable signal to the market regarding the individual's relative productivity. Even those students with a passion for music may benefit from an economics major, many colleges and universities afford students the opportunity to earn a double major as an undergraduate. ${ }^{1}$

This evidence aside, I appreciate Colander's core concern. The economics major may not be better at preparing an individual student for a career in business or finance relative to many other liberal arts majors. What is the best preparation for a career in business? Here I believe liberal arts colleges provide a compelling answer. The best major for business depends on the individual student.

The labor market for newly minted bachelor's degrees involves a matching problem in an environment of incomplete information. Employers know their needs, the set of skills they require and seek to fill these positions with highly productive individuals. Students seek jobs that match their inherent skills, a career that maximizes their earnings potential. Because neither side knows with certainty the individuals true productivity, signals garnered by the student through their choice of major may improve the match. 
While it is difficult to see an English major succeeding in analytical finance, it is much easier to see an English major succeeding on the sales side of a firm. English, as a major, enhances the individual's ability to communicate (both oral and written). On the other hand, it is relatively easy to see an economics major with strong analytical skills succeed on the analytical side of a finance firms operations. What major should the student prefer for a career in finance? This depends on the individual. A student with strong innate quantitative ability would logically pursue a major in economics, mathematics or statistics. This student would likely earn high marks because these disciplines match their skills, thereby providing a signal to the market on their strengths. A student with strong innate communication or writing skills would best pursue a major in English. In this setting the "writer" earns a 3.8 grade point average in English (as opposed to a 2.2 grade point average in economics) thereby providing a signal to the market on their strengths. ${ }^{2}$

Liberal arts colleges traditionally offer majors in the sciences and mathematics (biology, chemistry, physics, etc.), social sciences (economics, political science, sociology, etc.), humanities (English, history, philosophy, etc.) and the arts (music, art and art history, performance, etc.). Professor Colander highlights the general skills developed by liberal arts schools, but does not expound on another of the strengths of liberal arts institutions. Each of the traditional liberal arts majors can be framed around a set of analytical and critical thinking skills. It would not be fair to characterize each discipline as confronting a particular set of questions, the questions overlap across a variety of disciplines. Rather disciplines are defined by the unique critical thinking and analytic tools used to address a question or problem. The disciplines are better defined by their diversity of approach. How do we capitalize on this diversity of approach in preparing students for a career?

The pressure on economics majors has increased as families are increasingly concerned with college outcomes defined by careers (and pundits seem to increasingly focus on negative outcomes that are most likely outliers). In response to this pressure, St. Lawrence University, my home institution, has embraced an alternative model, one based on sound economic principals. Each student possesses a set of innate skills they bring to college. These have been developed and enhanced through their individual experiences before college enrollment. Our goal: Match innate skills to majors, we encourage students to find a major in which they have a comparative advantage. This is the natural consequence of a college's general education requirements. Students are pushed to take courses from a variety of disciplines and in the process learn where their comparative advantage lies.

St. Lawrence has recently developed the "Business in the Liberal Arts Major" that builds on this discovery process. The major is built around four requirements.

1. The student complete a double major.

2. The student satisfactorily complete a set of core courses.

3. The student satisfactorily complete a set of electives.

4. The student complete an experiential learning experience.

Starting with the second requirement, we recognize there are some core competencies that will aid an individual in a business environment. ${ }^{3}$ These courses include study in economics, accounting, statistics, and a course in reasoning taught by the philosophy department. Third, we ask students to take courses which will help them recognize the ways businesses interact with individuals and society both locally and globally. Fourth, we ask students to successfully complete an experiential learning experience which may range from an internship in business or a not-for-profit entity to study abroad.

The heart of the business in the liberal arts major lies in the first requirement, students must complete another major from among those majors offered at St. Lawrence. The business in the liberal arts major can only be done as a double major. Before declaring the 
Business in the Liberal Arts major (during the second semester of their sophomore year) students must identify their primary major. We encourage students to find a major at which they will achieve academic success, a major that matches their comparative advantage.

As Colander points out employers want employees that have strong "general liberal arts skills" defined as "self-starters, who can learn on their own, who can write, who can handle quantitative and qualitative reasoning, who are comfortable with critical thinking, who can deal with uncertainty, who can communicate verbally, and who play well with others in the sandbox" (i.e. are comfortable working in teams). This final skill may be the most important. Business decisions have always been and are increasingly made in a team environment. Businesses (be they in finance or otherwise) do not seek to bring together homogeneous teams, teams of individuals with similar skills. Rather businesses realize successful teams bring together individuals with a variety of critical thinking and analytical tools. The Business in the Liberal Arts major encourages the student to find that set of skills (that major) through which they will have the most to offer a firm.

\section{Notes}

1. Del Rossi and Hersch [2008] provide evidence of a wage increase associated with completing a double major as an undergraduate.

2. Associated with this argument is the parallel argument that as college professors we should maintain the rigor of our courses, to issue grades that provide to students and employers information on the students skill set.

3. For example, the ability to evaluate costs and benefits of an action, the ability to read an income statement and balance sheet, and the ability to understand basic statistical analysis.

\section{References}

Altonji, Joseph G., Erica Blom, and Costas Meghir. 2012. Heterogeneity in Human Capital Investments: High School Curriculum, College Major and Careers. Annual Review of Economics, 4(1): 185-223.

Black, Dan, Seth Sanders, and Lowell Taylor. 2003. The Economic Reward for Studying Economics. Economic Inquiry, 41(3): 365-77.

Del Rossi, Alison, and Joni Hersch. 2008. Double Your Major, Double Your Return? Economics of Education Review, 27(4): 375-386. 